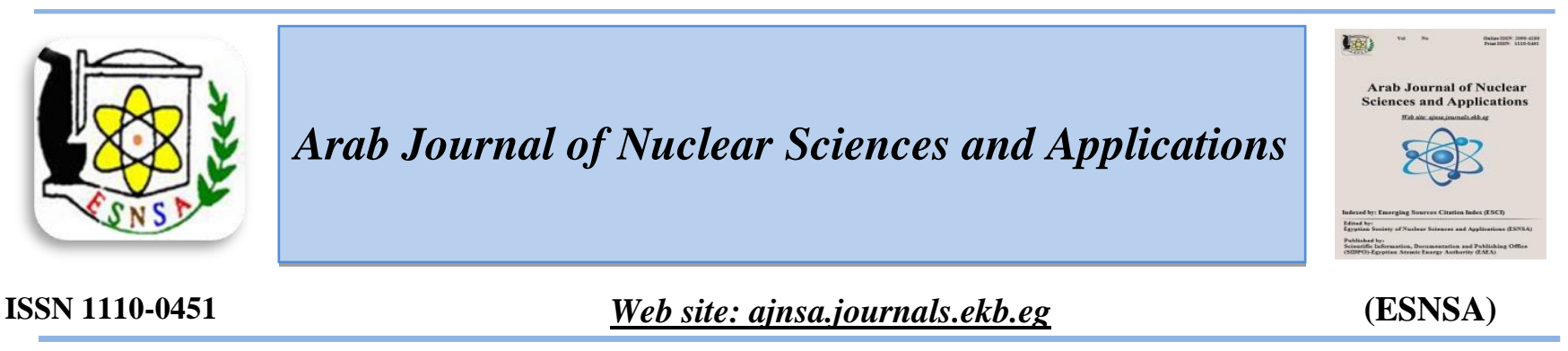

\title{
New Extraction Technique of Zirconium and Hafnium from Zircon Mineral
}

\author{
Ahmed Abdelkareem \\ Nuclear Materials Authority, Cairo, Egypt
}

Received $28^{\text {th }}$ Feb. 2018 The present study is concerned primarily with optimizing the extraction of zirconium and hafnium from Accepted $25^{\text {th }}$ Mar. their naturally occurring mineral, zircon, via a wet chemical process. First, zircon is heated with molten 2019 sodium hydroxide to form zironate and silicate frit. Simple separation technique of sodium silicate from the zirconate and hafnate sodium was then applied to obtain a silicate-free frit, then the extraction of the zirconium (IV) and hafnium (IV) basic sulfates from their oxychloride solution leaving almost all other ions soluble in the mother liquor was achieved by adjusting the $\mathrm{pH}$ value. The precipitate of zirconium (IV) and hafnium (IV) basic sulfates was dried, weighed, analyzed and the percentage of the zirconium and hafnium extracted were found to be $97 \%$ of their original concentration.

Keywords: Zircon mineral; Zirconium; Hafnium; Sulfate; Wet chemical

\section{Introduction}

Zirconium and hafnium compounds are widely used in today's technology. Zirconium or hafnium carbides and borides are high temperature ceramics that are used in aero propulsion, airframe and spacecraft structures, hypersonic vehicle systems, nuclear reactor core, and high-energy plasma [1-7]. Zirconium and hafnium oxides are structural ceramics used mainly as a refractory materials in building metallurgical furnaces, aerospace applications and nuclear reactors [5, 8]. Higher purity zirconium and hafnium oxides can be used as electroceramic in applications such as fuel cells, sensors and generation systems, filter, buzzer, spark generator [9-12]. Zirconium and hafnium compounds are also used in many biomedical applications including knee and hip replacements, dental implants and other restorative practices, and middle-ear ossicular chain reconstruction [13-15]. Zirconium and hafnium in their metallic forms are well known for their application in nuclear reactors and super alloys $[6,16,17]$. Nano particles of the metals are strong potential for applications such as energy conversion, catalysis, powder metallurgy, and nano composites [3, 18, 19].

The principal economic source of zirconium is the zirconium silicate mineral, zircon $\left(\mathrm{ZrSiO}_{4}\right)$. Zircon is one of the most chemically stable compounds $\left(\Delta \mathrm{G}^{\circ} 1400 \mathrm{~K}=1489.1 \mathrm{~kJ} / \mathrm{mol}\right)$. This is due to the high coordination of bisdisphenoid $\mathrm{ZrO}_{8}$ in a tetragonal structure with $\mathrm{SiO} 4$ tetrahedra $[19,20]$. Therefore, mineral acid other than HF cannot attack zircon and very aggressive reaction conditions are require to breakdown the strong binding between zirconium and silicon parts in the compound [21, 22]. One of the most industrial methods is the reaction of zircon with molten alkaline earth hydroxides to produce the acid soluble sodium zirconium (and hafnium) silicate according to reactions 1 and 2 [23]. The sodium silicate compounds (usually known as the frit) are conventionally treated with hot $\mathrm{HCl}$ to produce chlorides of zirconium and hafnium of which, 
other compounds of zirconim and hafnium can be synthesized [24].

$$
\begin{aligned}
& \mathrm{ZrSiO}_{4}+4 \mathrm{NaOH} \rightarrow \mathrm{Na}_{2} \mathrm{ZrO}_{3}+\mathrm{Na}_{2} \mathrm{SiO}_{3} \\
& \text { (disodium metasilicate) }+2 \mathrm{H}_{2} \mathrm{O}
\end{aligned}
$$

$$
\begin{aligned}
& \mathrm{ZrSiO}_{4}+6 \mathrm{NaOH} \rightarrow \mathrm{Na}_{2} \mathrm{ZrO}_{3}+\mathrm{Na}_{4} \mathrm{SiO}_{4} \text { (sodium } \\
& \text { orthosilicate) }+3 \mathrm{H}_{2} \mathrm{O}
\end{aligned}
$$

In early work, the fusion reaction was conducted in an insufficient amount of sodium hydroxide, and sodium zirconium silicate is obtained as a major product [25].

$$
\mathrm{ZrSiO}_{4}+2 \mathrm{NaOH} \rightarrow \mathrm{Na}_{2} \mathrm{ZrSiO}_{5}+\mathrm{H}_{2} \mathrm{O} \ldots
$$

The reaction of sodium zirconium (and hafnium) silicate with hydrochloric acid produces chlorides of zirconium and hafnium as well as silicon dioxide in the acidic solution as illustrated in equation (4) [26]. The silicic acid formed, when treating the frit with mineral acids, has amphoteric properties for an unknown cause, mud is formed which leads to consumption of additional quantities of the mineral acids, interferes the filtration process and the yield of the main extraction process of the zirconium and hafnium was as low as $33 \%$ [27].

$$
\begin{array}{r}
\mathrm{Na}_{2} \mathrm{ZrSiO}_{5}+4 \mathrm{HCl} \rightarrow 2 \mathrm{NaCl}+\mathrm{ZrOCl}_{2}+\mathrm{SiO}_{2}+ \\
2 \mathrm{H}_{2} \mathrm{O} \ldots \text { (4) }
\end{array}
$$

Zirconium basic sulfate plays a key role in the production of pure zirconium chemicals. The most common zirconium basic sulfate is $\mathrm{Zr}_{5} \mathrm{O}_{8}\left(\mathrm{SO}_{4}\right)_{2} \cdot \mathrm{nH}_{2} \mathrm{O}$, other basic sulfates have been formulated as the dodecahedral structure consisting of layers of $\mathrm{ZrO}_{8}$ bridged by sulfate ions and the square antiprism $\mathrm{Zr}(\mathrm{OH})_{2} \mathrm{SO}_{4}$, has infinite zigzag chains of $\left[\mathrm{Zr}(\mathrm{OH})_{2}\right]$ [28]. Precipitation of zirconium and hafnium in the form of basic sulfates was initially applied to extract zirconium and hafnium from impurities present together in their chloride solutions prepared by dissolving their commercial tetra chlorides in hydrochloric acid.

The present work represents a wet chemical method to optimize the extraction of zirconium and hafnium from zircon ore, and involves antiscavenging experiments. In the present study, a selective method for the extraction of zirconium and hafnium from the Egyptian mineral zircon was described. The use of ammonium sulfates to precipitate zirconium and hafnium basic sulfates is first used to precipitate them from their chloride solution prepared by dissolving the commercial tetra chlorides of zirconium and hafnium. The application of the sulfate ion effect to precipitate the basic sulfates of zirconium and hafnium from their oxy chloride solution prepared by direct dissolution of the washed frit silicate-free was accomplished.

\section{Experimental}

Chemicals and reagents

The zircon mineral was supplied from the black sand laboratories at the Nuclear Materials Authority (NMA) with $99.0 \%$ purity. The ammonium sulfate and sodium hydroxide are from Sigma-Aldrich. All chemicals and reagents used are of analytical grade without further purification and double-distilled water was used.

\section{Apparatus}

A 316-stainless steel chemical resistant crucible has been specially designed for the vigorous reaction of zirconium (and hafnium) silicates with sodium hydroxide. Analysis of the zircon mineral was carried out using the ICP-MS utilizing Perkin Elmer apparatus model OPTIMA3000. The X-ray fluorescence measurements were performed using an X-ray fluorescence spectrometer type (X'Unique II). The thermo gravimetric analysis was carried out using the Shimadzu TGA 50. The elemental analysis was carried out using thermo scientific apparatus type Flash 2000 and atomic absorption technique using Perkin-Elmer apparatus model Analyst 100 . The $\mathrm{pH}$ values were measured with Digimid $\mathrm{pH}$ meter. Spectrophotometric measurements were carried out in UV and visible regions using spectrophotometer "Genesis II" spectrophotometer.

\section{Procedure}

The zircon sample weighing $100 \mathrm{gm}$ was processed with $100 \mathrm{gm}$ of sodium hydroxide. A stoichiometric amount of sodium hydroxide with $20 \%$ excess was added to the equivalent amount of the mineral zircon composed mainly of zirconium silicate and hafnium silicate following equation (1). The mixture was stuffed in the form of layered sandwich in the stainless steel crucible 
to obtain maximum attaching during the fusion reaction course at $650^{\circ} \mathrm{C}$ for 2 hours. The resultant frit was allowed to cool down overnight.

The frit was exposed to an aqueous leach solution using the technique of continuous filtration, and the aqueous leach continued till complete silicate removing and the concentration of sodium silicate were checked up with spectrophotometric techniques.

The impurities of the zircon mineral were analyzed using ICP-MS technique, and the structure of the washed frit silicate-free was characterized with $\mathrm{X}$. ray fluorescence technique before being digested with hydrochloric acid.

A $50 \mathrm{~g}$ representative sample of the washed frit silicate-free was digested for an hour at $80^{\circ} \mathrm{C}$ in a stoichiometric $+10 \%$ amount of hydrochloric acid till almost all the powder was dissolved and a clear yellowish solution achieved. The solution was filtered to eliminate the unreacted zircon. The unreacted zircon was collected, dried and weighed. The oxy-chloride solution was diluted five times with distilled water and the $\mathrm{pH}$ value was kept less than 0.5 to maintain the zirconium and hafnium ions in the solution in the individual tetravalent ionic form $\mathrm{Zr}^{+4}$ and $\mathrm{Hf}^{+4}$ [18].

A molar ammonium sulfate solution was added gradually to the oxy chloride solution of the zirconium and hafnium with impurities, while the $\mathrm{pH}$ value was watched carefully through the course of precipitation till complete precipitation of a white precipitate of zirconium and hafnium sulfate obtained. The solution was stirred for an hour after complete precipitation to ensure complete reaction, and then the white precipitate of sulfates was left for two hours to be settled then filtered, washed with distilled water several times, collected and dried at room temperature under desiccators feeded with calcium chloride anhydrous.

The zirconium and hafnium sulfates extracted were scanned using $X$. ray fluorescence technique. The thermo gravimetric studies were carried out in nitrogen atmosphere with rate flow equals 30.0 $\mathrm{ml} / \mathrm{min}$ and temperature started at $22.4^{\circ} \mathrm{C}$, ended at $1100^{\circ} \mathrm{C}$ with temperature elevating rate 10.0 $\mathrm{C} / \mathrm{min}$.

The zirconium and hafnium in the zirconium and hafnium sulfates extracted were determined using spectrophotometric technique and their percentage was calculated with respect to their original amounts processed.

The elemental analysis of hydrogen, oxygen and sulfur in the zirconium and hafnium sulfates extracted was performed using Flash 2000 thermo scientific apparatus.

The zirconium and hafnium basic sulfates extracted were analyzed for titanium [21], yttrium [22], uranium [23] and thorium [24] spectrophotometrically. Iron, calcium, magnesium and aluminum were determined using the atomic absorption technique using Perkin-Elmer apparatus model Analyst 100.

The $\mathrm{pH}$ value of the mother liquor was raised gradually using ammonia solution till the $\mathrm{pH}$ value reached 2 and the solution watched carefully, then the solution filtered.

\section{Results and Discussion}

The results of the elemental analysis of the zircon mineral characterized, using ICP-MS technique, was performed and the results are shown in Table (1). It is clear from Table (1) that the elements present in noticeable concentrations in the mineral zircon also present in the XRF spectrum of the washed frit silicate-free are presented in Fig. (1), where the washing process with distilled water only aimed to eliminate the silicates to obtain silicate-free frit as a precursor to the acid leach.

The titanium, iron, aluminum and calcium present in the XRF spectrum of the silicate-free frit shown in Fig. (1) that are present in noticeable concentrations (and also in Table 1), completely disappeared in the XRF spectrum of the product of the sulfate process as clear in XRF spectrum of the produced basic sulfates represented in Fig. (2). From Fig. (1), it is clear that the yttrium which is present in the ICP analysis of the zircon mineral with concentration equals $0.13 \%$, has a peak in the XRF spectrum shown Fig. (1) appears to be present in a higher concentration which must be interpreted on the basis of interference or overlapping of this peak of the yttrium and that peak of the Rh-tube of the spectrometer itself at about 25 two-theta degrees of the X-ray goniometer. On the same basis, it could be understood that the apparent high concentration of titanium, cesium, calcium and cadmium are due to 
the overlapping with the main peak of zirconium already present in a comparatively high concentration.

The precipitation of the zirconium and hafnium basic sulfates from their oxy chlorides solution was achieved by adjusting the $\mathrm{pH}$ value and the precipitation started at $\mathrm{pH} 1.35$ and completed at $\mathrm{pH}$ 1.4. After complete precipitation at $\mathrm{pH}$ 1.4. The precipitate was filtered, and the mother liquor was analyzed for of $\mathrm{Zr}$ and $\mathrm{Hf}$ spectrophotometrically the zirconium and hafnium was not detected spectrophotometrically in the mother liquor after complete precipitation indicating almost complete precipitation.

The mother liquor was investigated by raising the $\mathrm{pH}$ value from 1.4 to 2 , then the mother liquor was filtered with no more precipitate obtained, indicating the validity of the method for the extraction of the zirconium and hafnium.

The yield of the extraction process of zirconium and hafnium was found to be improved from $33 \%$ to $97 \%$.

The white precipitate of zirconium sulfate and hafnium basic sulfate was analyzed for those elements with noticeable concentrations in the original analysis results of the zircon mineral summarized in Table (1). The results of spectrophotometric analysis for titanium, yttrium, uranium and thorium, and the results of analysis for iron, calcium, magnesium and aluminum using atomic absorption technique; show that all these elements were not detected indicating the high purity of the zirconium and hafnium basic sulfates and confirming the results of scanning the zirconium and hafnium sulfates with XRF technique represented in Fig. (2).

The zirconium and hafnium impurities-free basic sulfates produced were investigated with elemental analysis and the results are summarized in Table (2). The zirconium sulfate and hafnium sulfate produced impurities-free were investigated with thermo gravimetric analysis TGA. The thermal studies were carried out for the produced basic sulfates to go through light on the nature, the presence of water molecules, structure of the metal basic sulfates and its thermal stability. The TGA and Dr-TGA curves represented in Fig. (3) show a weight loss peak at $60.78^{\circ} \mathrm{C}$ corresponding to volatization of three molecules of water of hydration. The TGA curves show a continuous weight loss after the above degree corresponding to elimination of two molecules of $\mathrm{SO}_{3}$. The peak at 564.8 indicates the rest of the molecule which corresponds to five molecules of zirconium oxide. The TGA curves also show that the basic sulfates are thermally stable up to $564.8^{\circ} \mathrm{C}$. The results of elemental analysis coupled with the results of thermo gravimetric analysis indicated that the structure of the extracted zirconium sulfate was $\mathrm{Zr}_{5} \mathrm{O}_{8}\left(\mathrm{SO}_{4}\right)_{2} .3 \mathrm{H}_{2} \mathrm{O}$ and that of hafnium sulfate was $\mathrm{Hf}_{5} \mathrm{O}_{8}\left(\mathrm{SO}_{4}\right)_{2} .3 \mathrm{H}_{2} \mathrm{O}$.

\section{Conclusion}

The application of the sulfate ion effect to precipitate the sulfates of zirconium and hafnium from their oxy chloride solution provides valuable advantageous over the traditional techniques. One step separation of zirconium and hafnium from the present impurities and an economic dissolution of the frit in the minimal amount of hydrochloric acid instead of the many fold percent consumed in the traditional techniques and the yield of the extraction process of zirconium and hafnium was raised to $97 \%$. It is important to say that the sulfate precipitate will not be formed clear and in that percent otherwise the frit was silicate-free, the elimination process of the silicates from the frit was successfully accomplished in one-step process, and this work will be published as soon as possible.

\section{ACKNOWLEDGEMENT}

The author appreciates the efforts of the XRF lab and the analytical chemistry department in the Egyptian nuclear materials authority for their worthy cooperation 
Table (1): Analysis of zircon mineral

Analysis of Zircen Concenterte

\begin{tabular}{|c|c|c|c|}
\hline ANALYTE & $\begin{array}{c}\text { CONCENTRATION } \\
\times\end{array}$ & ANALYTE & $\begin{array}{c}\text { CONCENTRATION } \\
\%\end{array}$ \\
\hline $2 \mathrm{rO}$, & 65.47 & $\mathrm{Rb} .0$ & $<0.01$ \\
\hline $\mathrm{HO}_{\text {; }}$ & 1.32 & $\mathrm{C}, \mathrm{O}$ & $<0.01$ \\
\hline $\mathrm{SiO}_{2}$ & 32.58 & $\mathrm{~S}_{2} \mathrm{O}_{2}$ & $<0.01$ \\
\hline TiO, & 0.05 & $P_{1}, O_{11}$ & $\angle 0.01$ \\
\hline $\mathrm{N}, \mathrm{O}$, & 0.06 & $\mathrm{CS}_{\mathrm{O}} \mathrm{O}_{2}$ & 0.01 \\
\hline $\mathrm{Fe}_{0} \mathrm{O}_{2}$ & 0.05 & $\mathrm{Yb}_{2}$ & 0.03 \\
\hline $\mathrm{COO}$ & 0.03 & $\mathrm{H}_{0} \mathrm{O}_{2}$ & $<0.01$ \\
\hline $\mathrm{MSO}$ & $<0.05$ & $\mathrm{Y}, \mathrm{O}$ & 0.13 \\
\hline$P, O_{1}$ & 0.13 & $\mathrm{Nb}, \mathrm{O}_{1}$ & $<0.01$ \\
\hline$T_{2}, 0_{1}$ & $<0.01$ & L.O, & $<0.01$ \\
\hline$K, 0$ & $<0.01$ & $\mathrm{CoO}_{2}$ & $<0.01$ \\
\hline $\mathrm{N}_{2}, \mathrm{O}$ & $<0.1$ & $\mathrm{~N} \mathrm{~N}_{\mathrm{O}}$ & $<0.01$ \\
\hline $\mathrm{Bi}, \mathrm{O}_{2}$ & $<0.01$ & $\mathrm{Sm}_{2} \mathrm{O}_{2}$ & $<0.01$ \\
\hline $\mathrm{Cr}_{2} \mathrm{O}_{2}$ & $<0.01$ & $\mathrm{Eu}_{0} \mathrm{O}_{1}$ & $\angle 0.01$ \\
\hline $\mathrm{Mn}, \mathrm{O}_{1}$ & $\angle 0.01$ & $\mathrm{Dr}_{2} \mathrm{O}_{2}$ & $\angle 0,01$ \\
\hline $\mathrm{PbO}$ & $<0.01$ & $\mathrm{~Tb}_{\mathrm{O}, \mathrm{O}}$ & $\langle 0,01$ \\
\hline $\mathrm{ZnO}$ & $<0.01$ & $\varepsilon_{1} 0_{2}$ & ND \\
\hline $\mathrm{BO}$ & $<0.01$ & $\operatorname{Tm} \mathrm{O}_{2}$ & ND \\
\hline$V_{1}, O_{2}$ & $\angle 0.01$ & $L_{0,0}$ & $\mathrm{ND}$ \\
\hline $\mathrm{COO}$ & $\angle 0.01$ & $R_{c}, 0$. & NII) \\
\hline $\mathrm{NiO}$ & $\angle 0.01$ & $\mathrm{HSO}_{\mathrm{S}}$ & NI) \\
\hline $\mathrm{SnO}$ & $<0.01$ & $\ln , 0$, & सnSI \\
\hline $\mathrm{CuO}$ & $\angle 0.01$ & wo, & $\langle 0 \Omega|$ \\
\hline $\mathrm{As}_{3} \mathrm{O}_{3}$ & $<0.01$ & $0.0_{1}$ & $n 112$ \\
\hline $\mathrm{SnO}_{2}$ & $<0.01$ & Tho: & 0,02 \\
\hline $\mathrm{SB}_{2} \mathrm{O}_{2}$ & $<0,01$ & $\mathrm{BrO}$ & NI) \\
\hline $\mathrm{COO}$ & $\angle 0,01$ & $5 \times 0$. & $\mathrm{NI}$ \\
\hline $\mathrm{C}_{2} \mathrm{O}_{2}$ & $\langle 0.01$ & $\mathrm{TeO}_{2}$ & NI) \\
\hline $\mathrm{CeO}$. & $\langle 0,01$ & $\mathrm{RuO}_{\mathrm{N}}$ & $\mathrm{ND}$ \\
\hline $\mathrm{MoO}_{2}$ & $\langle 0.01$ & $\operatorname{loxi}$ On Isniten 'a $1025^{\circ} \mathrm{C}$ & 0.14 \\
\hline
\end{tabular}

Table (2): Results of elemental analysis of the zirconium and hafnium basic sulfates

\begin{tabular}{cccc}
\hline Element & $\mathrm{S}$ & $\mathrm{H}$ & $\mathrm{O}$ \\
\hline Determined \% & 7.6 & 0.7 & 36.6 \\
\hline
\end{tabular}




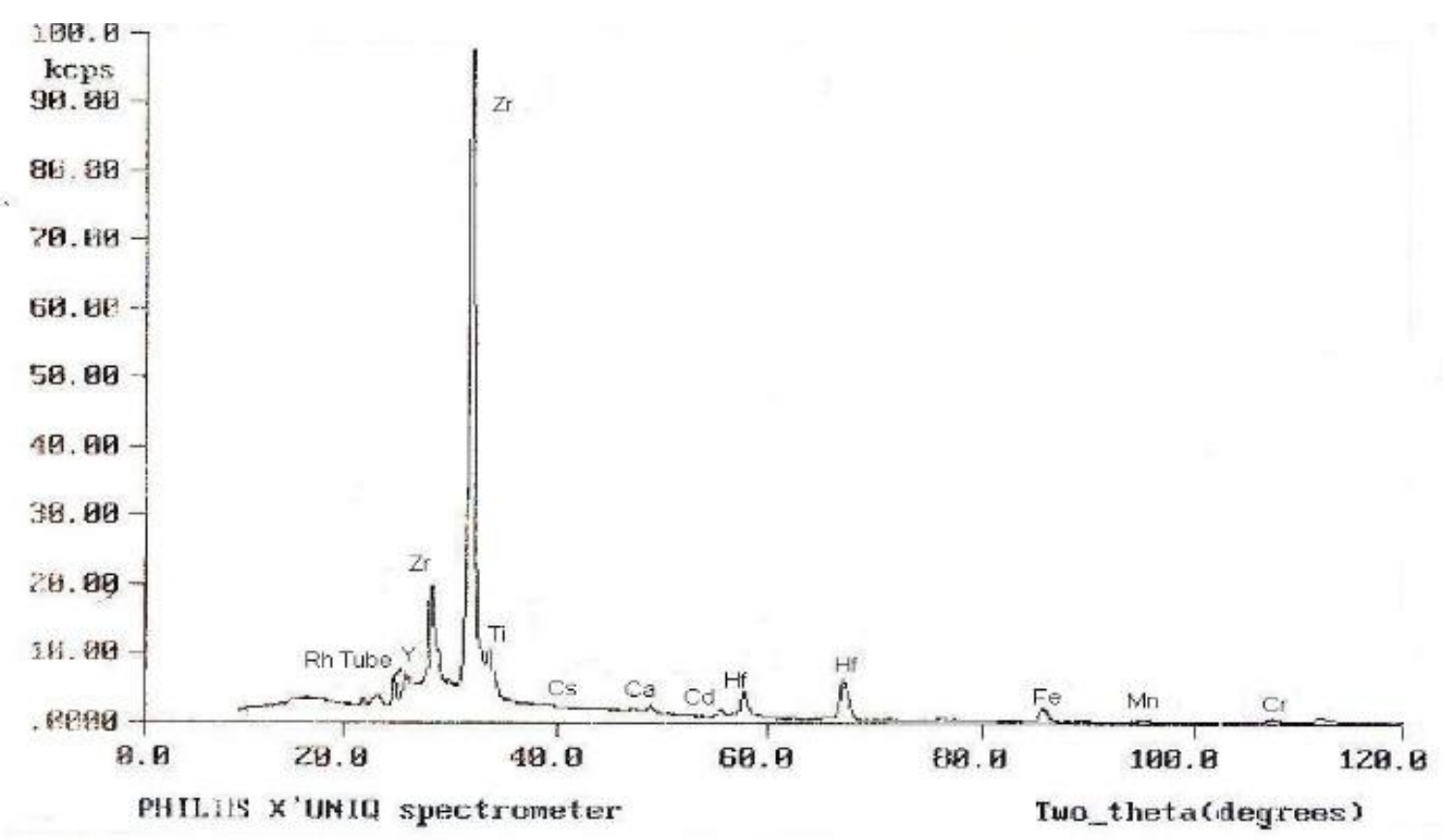

Fig. (1): XRF spectrum of the washed silicate-free frit

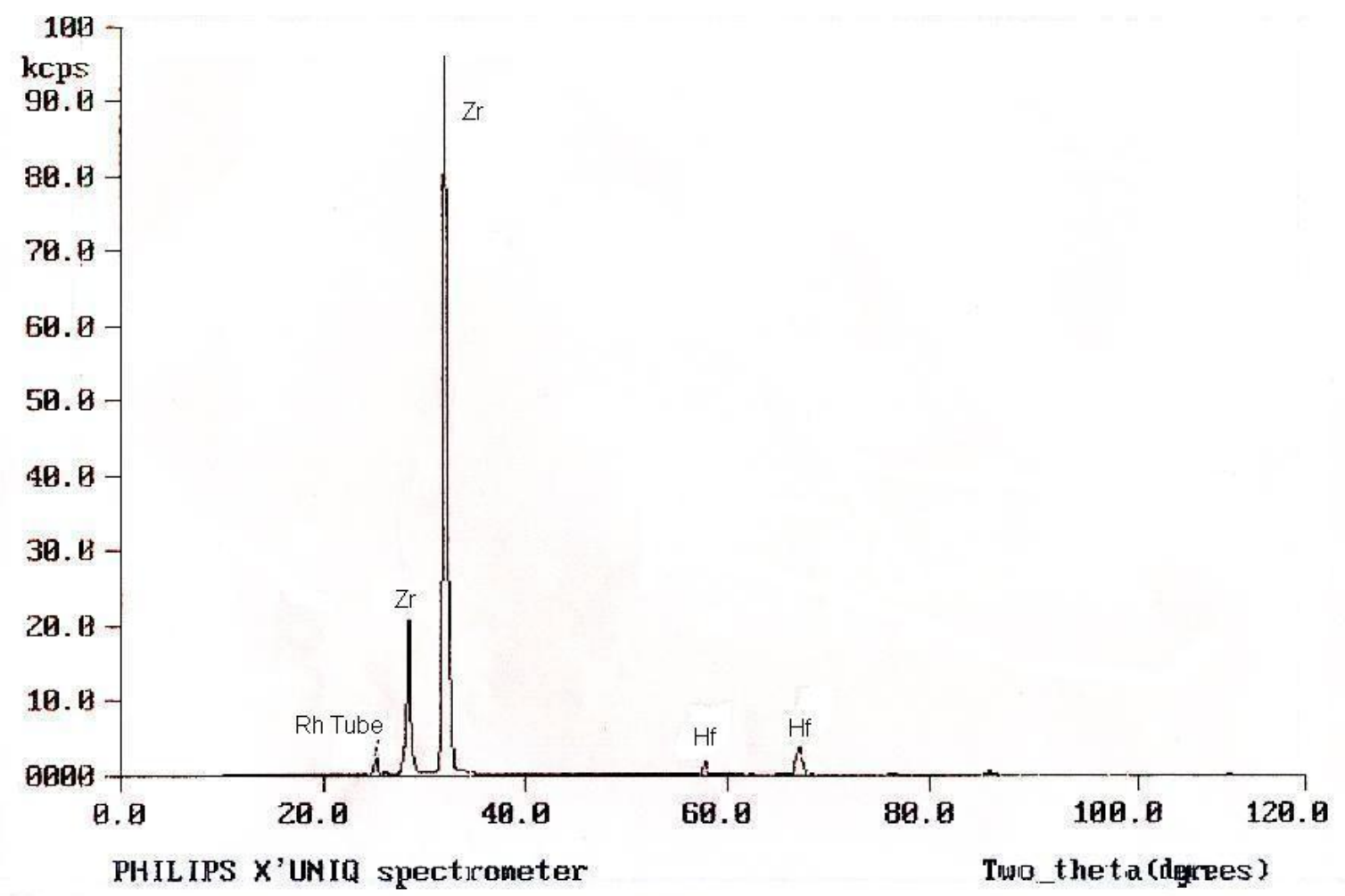

Fig. (2): XRF spectrum of the yield of the extraction process of zirconium and hafnium in their sulfate form 


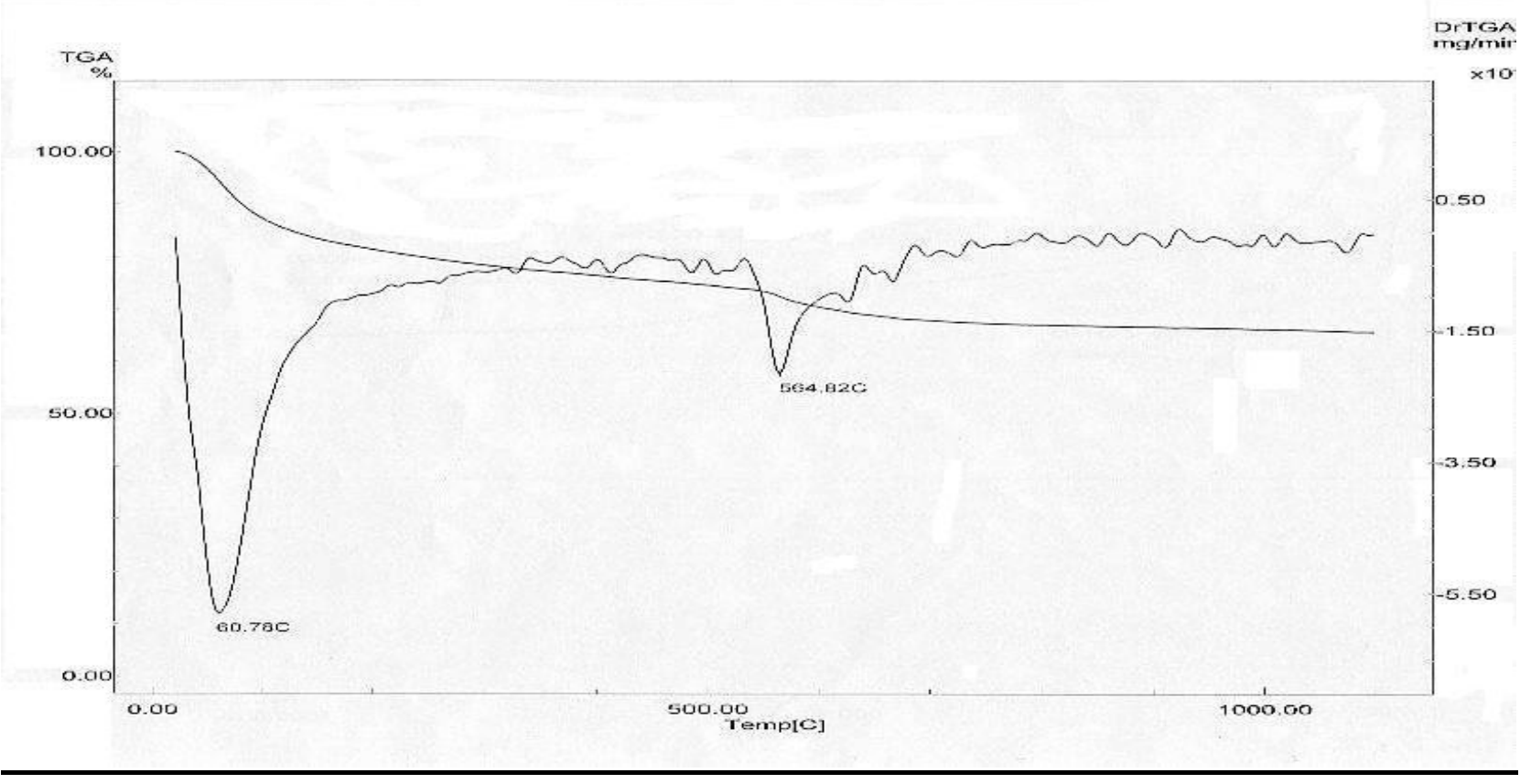

Fig. (3): Diagram showing the TGA and Dr TGA of the extracted basic sulfates

\section{References}

1. Levine, S.R., et al., Evaluation of ultra-high temperature ceramics for aeropropulsion use. Journal of the European Ceramic Society, 2002. 22(14-15): p. 2757-2767.

2. Sandhi, A., R.F. Reidy, and T.W. Scharf, Understanding the mechanism of zirconia to zirconium carbide conversion for ultra-hightemperature ceramic applications. American Ceramic Society Bulletin, 2013. 92(6): p. 56-56.

3. Abdelkader, A.M. and D.J. Fray, Synthesis of selfpassivated, and carbide-stabilized zirconium nanopowder. Journal of Nanoparticle Research, 2013. 15(12).

4. Zhang, S.C., G.E. Hilmas, and W.G. Fahrenholtz, Pressureless densification of zirconium diboride with boron carbide additions. Journal of the American Ceramic Society, 2006. 89(5): p. 15441550 .

5. Fahrenholtz, W.G., et al., Refractory diborides of zirconium and hafnium. Journal of the American Ceramic Society, 2007. 90(5): p. 1347-1364.

6. Heck, K., J.R. Blackford, and R.F. Singer, Castability of directionally solidified nickel base superalloys.

Materials Science and Technology, 1999. 15(2): p. 213-220.

7. Abdelkader, A.M. and E. El-Kashif, Calciothermic Reduction of Zirconium Oxide in Molten $\mathrm{CaCl}<\mathrm{sub}>2</$ sub $>$. ISIJ International, 2007. 47(1): p. 25-31.
8. Couland, M., et al., Novel Production Route of Yttria-Stabilized Zirconia Fuel Kernels and Pellets for Nuclear Fuel Applications. Journal of the American Ceramic Society, 2012. 95(1): p. 133-137.

9. Breen, J.P. and J.R.H. Ross, Methanol reforming for fuel-cell applications: development of zirconiacontaining $\mathrm{Cu}-\mathrm{Zn}-\mathrm{Al}$ catalysts. Catalysis Today, 1999. 51(3-4): p. 521-533.

10. Suetsugu, Y., et al., C3H6 sensing characteristics of rod-type yttria-stabilized zirconia-based sensor for ppb level environmental monitoring applications. Electrochimica Acta, 2012. 73: p. 118-122.

11. Ye, X.F., et al., Application of a $\mathrm{Cu}-\mathrm{CeO} 2 / \mathrm{Ni}$-yttriastabilized zirconia multi-layer anode for anodesupported Solid Oxide Fuel Cells operating on H-2CO syngas fuels. Journal of Power Sources, 2011. 196(13): p. 5499-5502.

12. Abdelkader, A. and A. DAHER, STUDIES ON THE PREPARATION OF PURE ZIRCONIA FROM ROSETTA ZIRCON VIA TWO ALTERNATIVE HYDROMETALLURGICAL PROCESSES. Isotope And Radiation Research, 2008. 40(1): p. 73-90.

13. Denry, I. and J.R. Kelly, State of the art of zirconia for dental applications. Dental Materials, 2008. 24(3): p. 299-307.

14. Manicone, P.F., P.R. Iommetti, and L. Raffaelli, An overview of zirconia ceramics: Basic properties and clinical applications. Journal of Dentistry, 2007. 35(11): p. 819-826.

15. Silva, V.V., F.S. Lameiras, and R.Z. Domingues, Microstructural and mechanical study of zirconia- 
hydroxyapatite $(\mathrm{ZH})$ composite ceramics for biomedical applications. Composites Science and Technology, 2001. 61(2): p. 301-310.

16. Gozlan, E., et al., ROLE OF ZIRCONIUM IN THE PHASE FORMATION AT THE INTERDENDRITIC ZONE IN NICKEL-BASED SUPERALLOYS. Journal of Materials Science, 1992. 27(14): p. 3869-3875.

17. Abdelkader, A. and A. Daher, Preparation of hafnium powder by calciothermic reduction of HfO 2 in molten chloride bath. Journal of Alloys and Compounds, 2009. 469(1): p. 571-575.

18. Epshteyn, A., et al., Sonochemically Generated AirStable Bimetallic Nanopowders of Group 4 Transition Metals with Aluminum. Chemistry of Materials, 2013. 25(6): p. 818-824.

19. Epshteyn, A., et al., Sonochemical Synthesis of AirInsensitive Carbide-Stabilized Hafnium Subhydride Nanopowder. Chemistry of Materials, 2009. 21(15): p. 3469-3472.

20.Zheng, Y.F., CALCULATION OF OXYGEN ISOTOPE FRACTIONATION IN ANHYDROUS SILICATE MINERALS. Geochimica Et Cosmochimica Acta, 1993. 57(5): p. 1079-1091.

21. Monaghan, S., J.C. Greer, and S.D. Elliott, Thermal decomposition mechanisms of hafnium and zirconium silicates at the atomic scale. Journal of Applied Physics, 2005. 97(11).

22. Meisel, T., et al., Determination of rare earth elements, $\mathrm{Y}, \mathrm{Th}, \mathrm{Zr}, \mathrm{Hf}, \mathrm{Nb}$ and $\mathrm{Ta}$ in geological reference materials G-2, G-3, SCo-1 and WGB-1 by sodium peroxide sintering and inductively coupled plasma-mass spectrometry. Geostandards Newsletter-the Journal of Geostandards and Geoanalysis, 2002. 26(1): p. 53-61.

23. Abdelkader, A.M., A. Daher, and E. El-Kashef, Novel decomposition method for zircon. Journal of Alloys and Compounds, 2008. 460(1-2): p. 577-580.

24. Biswas, R.K., et al., Preparation of Some Useful Compounds of Zirconium from Bangladeshi Zircon. Industrial \& Engineering Chemistry Research, 2012. 51(42): p. 13552-13561.

25. Hancock, J.D., REVIEW OF CONVENTIONAL AND NOVEL PROCESSES FOR THE EXTRACTION OF ZIRCONIA FROM ZIRCON. Miner Sci Eng, 1977. 9(1): p. 25-31.

26. Biswas, R.K., et al., A novel method for processing of Bangladeshi zircon: Part I: Baking, and fusion with $\mathrm{NaOH}$. Hydrometallurgy, 2010. 103(1-4): p. 124-129.

27. Manhique, A., Z. Kwela, and W.W. Focke, De wet process for the beneficiation of zircon: Optimization of the alkali fusion step. Industrial and Engineering Chemistry Research, 2003. 42(4): p. 777-783.
28. Da Silva, R.J.F., A.J.B. Dutra, and J.C. Afonso, Alkali fusion followed by a two-step leaching of a Brazilian zircon concentrate. Hydrometallurgy, 2012. 117-118: p. 93-100. 